\title{
Microbial Inoculants for Sustainable Agriculture
}

\author{
Aarti Yadav \\ Department Microbiology, CCS Haryana Agricultural University, Hisar - 125004, India \\ *Corresponding author
}

A B S T R A C T

\begin{tabular}{|l|}
\hline K e y w o r d s \\
$\begin{array}{l}\text { Biofertilizer, } \\
\text { Bioinoculants, Chemical } \\
\text { fertilizer and } \\
\text { Microorganism }\end{array}$ \\
\hline Article Info \\
\hline $\begin{array}{l}\text { Accepted: } \\
\text { 07 April 2018 } \\
\text { Available Online: } \\
\text { 10 May 2018 }\end{array}$ \\
\hline
\end{tabular}

\section{Introduction}

Soil microorganisms are critical part of sustainable agriculture and soil biodiversity framework. They play a vital part in the plant development and growth. In recent years, it is being seen that over application of synthetic fertilizers and pesticides which fall apart soil fertility as well as make few ecological effects. Beneficial microorganisms offer the possibility to meet our farming needs and in this manner, are better options for maintaining soil health and as an important part of integrated nutrient management for sustainable agricultural practice. When contrasted with the synthetic fertilizers, biofertilizers are more secure with diminished ecological harm, has more focused on movement and compelling in littler amounts.
Moreover, their multiplication can be controlled by the plant and indigenous microorganisms. In addition, microbial inoculants have faster decay systems and are less inclined to incite protection by the pathogens and bugs. Bio-inoculants for agriculture reason are called bio-fertilizers. Very often, microorganisms are not as efficient in natural surroundings as one would expect them to be and therefore, artificially multiplied cultures of efficient selected microorganisms play a vital role in accelerating the microbial processes in soil. Use of biofertilizers in the form of liquid microbial consortia is one of the important components of integrated nutrient management as these are cost effective and renewable source of plant nutrients to supplement the chemical fertilizers for 
sustainable agriculture. "Biofertilizers are defined as preparations containing living cells or latent cells of efficient strains of microorganisms that help crop plants in uptake of nutrients by their interactions in the rhizosphere when applied through seed or soil. They accelerate certain microbial processes in the soil which augment the extent of availability of nutrients in a form easily assimilated by plants" Biofertilizers include: nitrogen fixing biofertilizers (Rhizobium, Bradyrhizobium, Azospirillum and Azotobacter), phosphate solubilizing biofertilizers (PSB) (Bacillus, Pseudomonas, Aspergillus etc.), phosphate mobilizing biofertilizers (Mycorrhiza), plant growth promoting biofertilizers, potassium solubilizing bacteria, solubilizing bacteria and so on, however some of these genera incorporate endophytic species too. The bestdescribed endophytic microbes incorporate Azoarcus spp, Gluconaceto bacter diazotrophicus and Herbaspirillum seropedicae and so on. The utilization of biofertilizer is well beneath its maximum potential, fundamentally due to nonaccessibility of suitable inoculants. In this way, additionally studies on bioinoculants and their exploration will definitely help to comprehend the complexity and dynamism of microbial functioning and their compatibility in soils.

\section{Plant growth promoting rhizobacteria}

The rhizosphere, the zone encompassing and influenced by plant roots, is a problem area for a few life forms and a standout amongst the most composite biological communities on Earth (Mendes et al., 2013). The rhizosphere is the natural surroundings for a few microscopic organisms, archaea, parasites, green growth, infections, oomycetes, nematodes, arthropods and protozoa. Mendes et al., (2013) explained the rhizosphere microbiome as far as "the great" (beneficial microorganisms), "the terrible" (plant pathogens) and "the appalling" (human pathogens). Through different mechanisms plant beneficial microorganisms enhance their growth and development as well as shield them from pathogen. PGPRs can stimulate plant's development either directly or indirectly.

Coordinated mechanisms involve the synthesis of substances like phytohormones, release of nutrients and induction of induced systemic resistance. Several Phosphate $(\mathrm{P})$ solubilizing microbes (PSB) viz. Xanthomonas sp. Pseudomonas sp., Pseudomonas striata, Rhizobium japonicum, $R$. leguminosarum, Azotobacter chroococcum, Enterobacter aerogens, Burkholderia cepacia and some diazotrops. Different PGPR and their mode of action are listed in table 1 . Moreover, indirect mechanisms include induction of of symbiotic relationships for root development and biocontrol potential. In many cases various systems are involved to maintain beneficial plant microbial associations (Nihorimbere $e t$ al., 2011). Therefore, in present scenario the identification of the mechanisms responsible of plant development and growth is a big challenge.

\section{PGPR under abiotic stress}

It has been expected that the rhizosphere microbial groups adds to the capacity of some plant species to get by under outrageous condition (Mendes et al., 2013). For instance, halo-tolerant microorganisms flourish under salt-stretch conditions and help in promoting plant growth and development (Jorquera et al., 2012). Upadhyay et al., (2009) demonstrated the capacity of creating indole-3-acidic corrosive, P-solubilization, siderophores generation and $\mathrm{N}_{2}$ fixation. By 24 halotolerant microbes isolated from the rhizosphere of wheat plants developed in a saline zone. 
Table.1 Mode of action of PGPR

\begin{tabular}{|c|c|c|c|c|}
\hline \multirow{5}{*}{ Diazotrophs } & ORGANISM & Mode of action & Example & Refernces \\
\hline & Rhizobia & $\begin{array}{l}\text { Reduce } \mathrm{N}_{2} \text { to } \\
\mathrm{NH}_{3} \\
\text { (NITROGEN } \\
\text { FIXATION) }\end{array}$ & $\begin{array}{l}\text { Rhizobia, Frankia, } \\
\text { Azospirillum } \\
\text { Pseudomonas }\end{array}$ & $\begin{array}{l}\text { Kumar et al., } \\
\text { 2014; Suyal et } \\
\text { al., } 2014\end{array}$ \\
\hline & Azotobacter & $\begin{array}{l}\text { Produced } \\
\text { ammonia, } \\
\text { vitamins, growth } \\
\text { substances, } \\
\text { indole acetic } \\
\text { acid, gibberllins, } \\
\text { cytokinins }\end{array}$ & $\begin{array}{l}\text { Azotobacter } \\
\text { chroococcum, } \\
\text { A. vinelandii, } \\
\text { A. beijerinckii, } \\
\text { A. paspali, } \\
\text { A. armeniacus, } \\
\text { A. nigricans } \\
\text { A. salinestri }\end{array}$ & $\begin{array}{l}\text { DeLuca et al., } \\
\text { 1996; Verma et } \\
\text { al., } 2001\end{array}$ \\
\hline & Acetobacter & $\begin{array}{l}\mathrm{N}_{2} \text { fixation, } \\
\text { production of } \\
\text { plant growth- } \\
\text { promoting } \\
\text { substances }\end{array}$ & $\begin{array}{l}\text { Acetobacter, } \\
\text { Gluconacetobacter, } \\
\text { Gluconobacter, } \\
\text { Acidomonas }\end{array}$ & $\begin{array}{l}\text { Suyal et al., } \\
2014\end{array}$ \\
\hline & Pseudomonas & $\begin{array}{l}\text { Plant growth } \\
\text { promotion } \\
\text { activities }\end{array}$ & $\begin{array}{l}P . \text { jesenii } \\
P . \text { migulae }\end{array}$ & $\underset{2014}{\text { Kumar et al., }}$ \\
\hline $\begin{array}{l}\text { Phosphate } \\
\text { solubilizing } \\
\text { microorganisms }\end{array}$ & $\begin{array}{l}\text { Phosphate } \\
\text { solubilizing } \\
\text { bacteria (PSB) }\end{array}$ & $\begin{array}{l}\text { Solubilize } \\
\text { inorganic } \\
\text { phosphates }\end{array}$ & $\begin{array}{l}\text { Pseudomonas, } \\
\text { Bacillus, } \\
\text { Arthrobacter, } \\
\text { Rhodococcus, } \\
\text { Serratia, } \\
\text { Gordonia, } \\
\text { Phyllobacterium }\end{array}$ & Rani et al., 2013 \\
\hline Mycorrhiza & $\begin{array}{l}\text { Mycorrhiza } \\
\text { Arbuscular } \\
\text { mycorrhizal } \\
\text { fungi (AMF), }\end{array}$ & $\begin{array}{l}\text { Soil exploration } \\
\text { and increasing } \\
\text { uptake and } \\
\text { supply of } \mathrm{N}, \mathrm{P} \text {, } \\
\mathrm{K}, \mathrm{Zn}, \mathrm{Cu}, \mathrm{S}, \mathrm{Fe} \text {, } \\
\mathrm{Ca}, \mathrm{Mg} \text { and } \mathrm{Mn} \\
\text { to the host roots }\end{array}$ & Glomeromycota & Mallik, 2000 \\
\hline
\end{tabular}

There is great interest in agriculture and horticulture for bacterial and fungal inoculants that enhance growth of plants under low temperature (Mendes et al., 2013). For example, Burkholderia phytofirmans PsJN increased grapevine root growth and physiological activity at $4{ }^{\circ} \mathrm{C}$ (Mendes et al.,
13). Other abiotic factors that may badly affect plant growth are $\mathrm{pH}$ and high concentrations of toxic compounds. Low $\mathrm{pH}$ soils or contaminated soils are main challenges in many production systems worldwide. Kawasaki et al., (2012) used a split-root model and a combination of $\mathrm{T}$ - 
RFLP, DGGE, and 16SrRNA gene pyro sequencing and showed that Trifolium and other legumes respond to polycyclic aromatic hydrocarbons contamination in a systemic manner. Similarly, Rani et al., (2013) explored cadmium $(\mathrm{Cd})$ resistant $P$. putida 710A for Vigna radiata (L.) Wilczek plant growth promotion and metal sequestering in $\mathrm{Cd}$ polluted soils. Also, fungi play an important role in rhizo remediation, for example, inoculation of the endophytic fungus Lewia $s p$. in the rhizosphere of Festuca arundinacea (Cruz-Hernandez et al., 2012).

\section{Bioinoculants as biofertilizers}

In last few years, Rhizobia, constituting about $79 \%$ of the global demand of bio-inoculants, Phosphate-solubilizing bioinoculants comprise $15 \%$, with other bio-inoculants (Transparency Market Research, 2014; Owen et al., 2014). Due to the wide application of Azospirillum, it heads a long list of commercial free living PGPR products that are applied to crops in formulations. Some of the bioinoculants used as both biocontrol agent as well as for enhancing plant growth and development. Furthermore, at commercial level Bacillus subtilis is used amongst the most critical types of PGPR utilized under trade names such as Serenade, Kodiak, etc for crops like pea, cotton, beans, vegetables, rice and soybean.

Likely for fruit, nuts, ornamentals and trees PGPR developed by trades names Diegall, Nogall using Agrobacterium radiobacter as microbial agent. At long last, Pseudomonas fluorescens has likewise been utilized to produce commercial inoculants under the trade names Conquer and Victus and in the form of teeka by CCS HAU, Hisar. Despite their established economic and ecological benefits the utilization of such PGPR as biofertilizer must be deliberately evaluated due to their importance as opportunistic pathogens (Mendes et al., 2013). These microbial inoculants are available in both form liquid and with solid carriers.

Other than promoting plant growth and development, bioinoculants can mitigate both biotic and abiotic stress on crops, in this way, giving an ecological safe option for sustainable development. However, effective usage of microbial bioinoculants is depends on time span of usability or shelflife, variability in environment, diverse plants species and soil form or health. Besides, the irregularity of bio-inoculant execution and absence of free approval does little to fabricate confidence in their efficacy. In this way, more rudimentary information is required about microbial response, their interaction with both biotic and abiotic factors and for sustainable agriculture maintainable horticulture.

\section{References}

Cruz-Hernandez, A., Tomasini-Campocosio, A., PerezFlores, L., Fernandez-Perrino, F. and Gutierrez, R. M. 2012. Inoculation of seed-borne fungus in the rhizosphere of Festuca arundinacea promotes hydrocarbon removal and pyrene accumulation in roots. Plant Soil 363: 261-270

DeLuca, T.H., Drinkwater, L.E., Wiefling, B.A., DeNicola, D.M. 1996. Free-living nitrogen-fixing bacteria in temperate cropping systems: Influence of nitrogen source. Biol Fertil Soils 23: 140-144

Jorquera, M.A., Shaharoona, B., Nadeem, S.M., de la Luz Mora M and Crowley, D.E. 2012. Plant growth-promoting rhizobacteria associated with ancient clones of creosote bush (Larrea tridentata). Microb Ecol 64: 1008-1017

Kawasaki, A., Watson, E.R. and Kertesz, M.A. 2012. Indirect effects of 
polycyclic aromatic hydrocarbon contamination on microbial communities in legume and grass rhizospheres. Plant Soil 358: 169-182

Kumar, S., Suyal, D.C., Dhauni, N., Bhoriyal, M. and Goel, R. 2014. Relative plant growth promoting potential of himalayan psychrotolerant Pseudomonas jesenii strain MP1 against native Cicer arietinum L., Vigna mungo (L.) hepper; Vigna radiata (L.) Wilczek., Cajanus cajan (L.) Millsp. and Eleusine coracana (L.) Gaertn. Afr J Microbiol 8(50): 3931-3943

Mallik, A.M. 2000. Association of arbuscular mycorrhizae with some varieties of Tobacco (Nicotiana tobacum L.) and its effect on their growth, nutrition and certain soilborne diseases, Ph.D. thesis, Bharathidasan University, Tiruchirapalli, S. India, p 104

Mendes, R., Garbeva, P., and Raaijmakers, J.M. 2013. The rhizosphere microbiome: significance of plant beneficial, plant pathogenic, and human pathogenic microorganisms. FEMS Microbiol Rev., 37(5): 634-663

Nihorimbere, V., Ongena, M., Smargiassi, M., and Thonart, P. 2011. Beneficial effect of the rhizosphere microbial community for plant growth and health. Biotechnol Agron Soc Environ., 15(2): 327-337

Owen, D., Williams, A.P., Griffith, G.W. and Withers, P.J.A. 2014. Use of commercial bio-inoculants to increase agricultural production through improved phosphorous acquisition. Appl Soil Ecol 86: 41-54

Rani, A., Shouche, Y. and Goel, R. 2013. Comparative in situ remediation potential of Pseudomonas putida 710A and Commamonas aquatica 710B using plant (Vigna radiata (L.) wilczek) assay. Ann Microbiol 63(3):923-928

Suyal, D.C., Shukla, A., Goel, R. 2014. Growth promotory potential of the psychrophilic diazotroph Pseudomonas migulae S10724 against native Vigna radiata (L.) Wilczek. 3 Biotech 4: 665668

Transparency Market Research. 2014. Biofertilizers (Nitrogen fixing, phosphate solubilizing and others) market for seed treatment and soil treatment applications - global industry analysis, size, share, growth, trends and forecast, 2013-2019. Transparency Market Research, Allbany.

Upadhyay, S.K., Singh, D.P. and Saikia, R. 2009. Genetic diversity of plant growth promoting rhizobacteria isolated from rhizospheric soil of wheat under saline condition. Curr Microbiol 59: 489-496

Verma, S., Kumar, V., Narula, N. and Merbach, W. 2001. Studies on in vitro production of antimicrobial substances by Azotobacter chroococcum isolates/mutants. J Plant Dis Protect 108: $1152-1165$

\section{How to cite this article:}

Aarti Yadav. 2018. Microbial Inoculants for Sustainable Agriculture. Int.J.Curr.Microbiol.App.Sci. 7(05): 800-804. doi: https://doi.org/10.20546/ijcmas.2018.705.097 